\title{
PENGARUH COUNTRY OF ORIGIN PERCEPTION, PERCEIVED QUALITY DAN PROMOTIONAL MIX TERHADAP PURCHASE INTENTION DENGAN BRAND IMAGE SEBAGAI VARIABEL INTERVENING (STUDI PADA SMARTPHONE BUATAN INDONESIA)
}

\author{
Ni Made Rastini \\ I Nyoman Nurcaya \\ Universitas Udayana
}

\begin{abstract}
This study aims to analyze the influence of Country of Origin Perception, Perceived Quality and Promotion on Brand Image and Purchase Intention. Then to analyze whether Brand Image always affect consumers to make purchases of products especially smartphones made in Indonesia. To achieve that goal used as many as 125 respondents taken by purposive sampling with questionnaires as a method of data collection. The data is processed by means of analysis of Structural Equation Modeling. The results show that Country of Origin Perception, Perceived Quality and Promotion affect Purchase Intention either without or through Brand Image. Thus, it is suggested that Indonesian smartphone business players are expected to increase their promotion intensity and product performance in order to be able to build a consumer brand image that will ultimately affect the buying interest of Indonesian smartphone consumers.

Keywords : Country Of Origin, Consumer Perception, Promotion Brand Image, Purchase Intention
\end{abstract}

\section{PENDAHULUAN}

Di era globalisasi telah terjadi ketatnya persaingan ekonomi dan bisnis dengan munculnya perusahaan - perusahaan baru, sehingga menjadi suatu pekerjaan rumah bagi perusahaan lama agar dapat tetap bertahan. Salah satu upaya untuk tetap bertahan dalam kompetisi yang semakin kuat ini yaitu dengan memiliki manajemen pemasaran yang baik seperti memiliki kekuatan pada marketing mix maupuan marketing communication. Menurut Shimp (2003) marketing communication adalah hal yang mempresentasikan gabungan semua unsur dalam bauran pemasaran merek, yang memfasilitasi terjadinya pertukaran dengan menciptakan suatu arti yang disebarluaskan kepada pelanggan atau klien. Salah satu bentuk dari marketing communication adalah iklan. Sesungguhnya saat atau setelah perusahaan melakukan kegiatan promosi, perusahaan seharusnya mengalami peningkatan popularitas maupun penjualan. Namun hal ini tidak terjadi pada produsen smartphone buatan Indonesia seperti merek Evercoss, Mito maupun Advan. Smartphone merek-merek tersebut ternyata tidak mampu mencapai posisi 3 besar Top of Brand 
Indoseia (TBI), bahkan capaian market share selalu dikalahkan oleh smartphone merek luar negeri seperti Samsung.

Penyebab rendahnya persentase market share smartphone buatan Indonesia yaitu karena rendahnya minat beli konsumen. Selain promotion ada beberapa faktor yang mempengaruhi minat beli konsumen salah satunya adalah persepsi seperti persepsi mengenai Country of Origin Perception dan Perceived Quality yang diperkirakan dapat meningkatkan minat beli konsumen melalui peningkatan Brand Image. Penelitian ini bertujuan untuk menganalisis dan menjelaskan pengaruh dari Country of Origin Perception, Perceived Quality dan Promotion terhadap Brand Image dan Purchase Intention.

\section{TINJAUAN PUSTAKA}

\section{Purchase Intention}

Purchase Intention (Intensi Pembelian) adalah suatu proses pengambilan keputusan yang dilakukan oleh konsumen sebelum melakukan transaksipembelian atas suatu produk yang dibutuhkan. (Anoraga, 2000). Sikap tersebut akan berlangsung hingga konsumen mendapatkan kepuasan dari produk yang dibelinya, sehingga konsumen akan tetap setia untuk menggunakan produk tersebutdan bahkan konsumen akan merekomendasikan produk tersebut pada orang laian untuk ikut mengkonsumsi produk tersebut. Intensi sendiri ada tiga jenis konstruk, yaitu (1) intensi sebagai harapan, (2) intensi sebagai rencana, dan (3) intensisebagai keinginan.(Soderlund dan Ohman, 2003).

\section{Country of Origin Perception}

Country of Origin Perception (COO) adalah segala suatu bentuk persepsi konsumen atas produk dari suatu negara berdasarkan persepsi konsumen sebelumnya mengenai kelebihan dan kekurangan produksi dan pemasaran dari negara yang bersangkutan.(Roth dan Romeo). Berdasarkan penelitian yang sebelumnya pernah dilakukan, konsep dari Country of Origin Perception terus mengalami perkembangan yang awalnya mulai dari sebuah persepsi yang kemudian berdampak pada dilakukannya labelling pada suatu produk yang saat ini lebih dikenal dengan pemberian label made in. Studi mengenai Country Of Origin atau yang lebih dikenal dengan COO sudah berlangsung sejak tahun 1960an, dan penelitan pertama mengenai dampak dari COO 
dilakukan oleh Schooler pada tahun 1965 yang menyatakan bahwa memang COO ini memiliki dampak.

\section{Perceived Quality}

Hellier et al. (2003), Spais dan Vasileiou (2006) mendefinisi perceived quality sebagai penilaian konsumen secara keseluruhan terhadap atribut produk. Dalam penelitian yang dilakukan Hellier et al. (2003), perceived quality diukur dengan performa jasa, kecepatan dalam penyampaian jasa, ketanggapan karyawan, kepercayaan konsumen terhadap perusahaan dan tingkat pemahaman perusahaan terhadap kebutuhan konsumen. Sedangkan Spais dan Vasileiou (2006) menggunakan credence quality, search quality dan experience quality untuk mengukur variabel ini. Studi yang berbeda mendefinisi persepsi kualitas sebagai penilaian konsumen atas entitas kesempurnaan atau superioritas yang selanjutnya diukur dengan menggunakan dimensi penampilan fisik, keandalan, ketanggapan, jaminan dan empati (Wisnalmawati, 2005).

\section{Promotional mix}

Strategi promosi yang dilakukan oleh perusahaan dipengaruhi juga oleh jenis produknya, apakah barang konsumsi, barang spesial, konvinien, atau barang shopping. Juga pada barang industri cara mempromosikannya juga berbeda seperti instalasi akan berbeda pada supplies. Strategi yang diambil dalam mempromosikan barang dipengaruhi oleh tahap-tahap siklus kehidupan barang tersebut. Pada tahap perkenalan, perusahaan harus menjual kepada pembeli dengan mempromosikan produk tersebut secara umum. Begitu pula yang terjadi pada tahap pertumbuhan, kedewasaan dan periklanan.Sedangkan pada tahap penurunan, perusahaan harus membuat produk baru atau produk yang lebih menarik. Dari definisi dapat disimpulkan bahwa variabel Promotional Mix ada empat yaitu ;(a). Periklanan, merupakan bentuk komunikasi non individu dengan sejumlah biaya dengan media tertentu yang dilaksanakan oleh perusahaan, organisasi non laba ataupun para individu.(b). Personal Selling, merupakan usaha untuk memperkenalkan suatu produk melalui komunikasi langsung (tatap muka) agar konsumen tertarik untuk membeli produk yang ditawarkan.(c.) Publisitas. 


\section{Brand Image}

Citra merek atau brand image merupakan pengertahuan tentang merek yang berdasarkan konsumen (consumer - based brand knowledge).Citra merek (brand image) dapat dianggap sebagai jenis asosiasi yang muncul di benak konsumen ketika mengingat sebuah merek tertentu. (Shimp: 12). Dalam pengasosiasiannya, citra merek dapat dikonseptualisasikan berdasarkan jenis, dukungan, kekuatan, dan keunikan.Untuk jenis, terpecah lagi menjadi tiga konseptual yaitu atribut, manfaat, dan evaluasi keseluruhan (sikap).Dalam meningkatkan citra merek biasanya perusahaan melakukan branding, yaitu kumpulan kegiatan komunikasi yang dilakukan oleh perusahaan dalam rangka proses membangun dan membesarkan merek atau brand (Amalia E. Maulana, 2010)

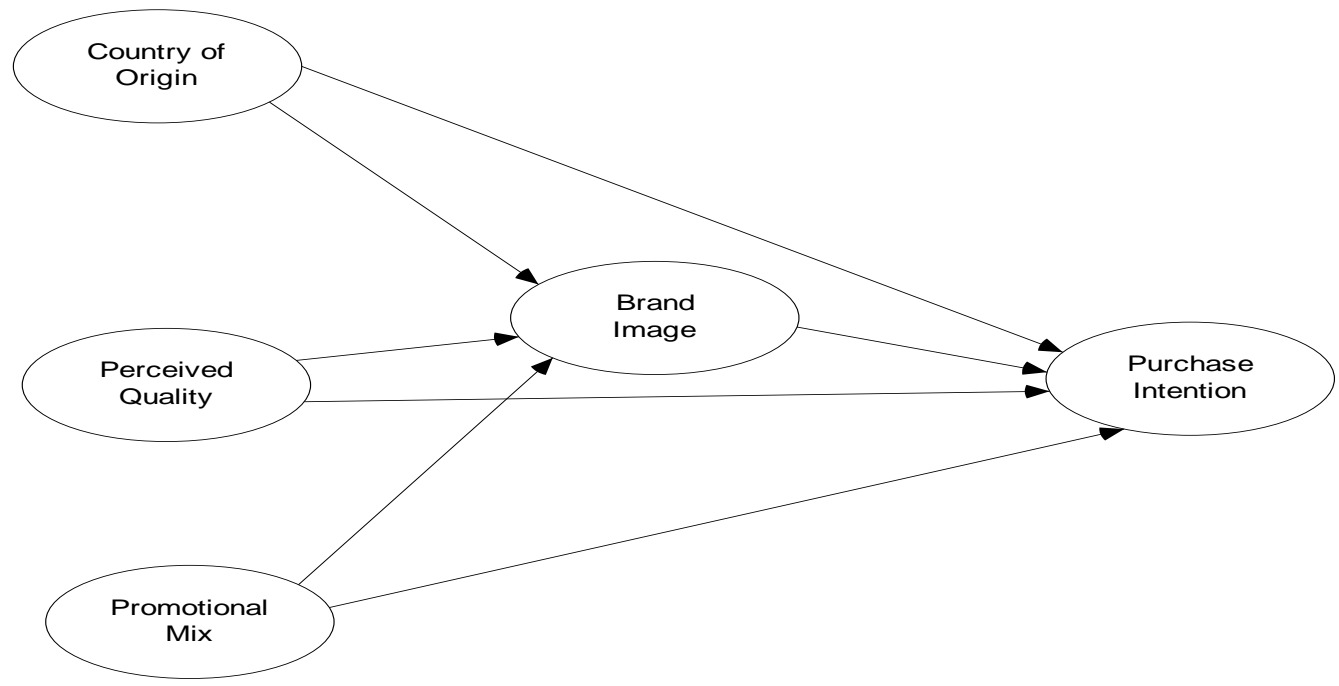

Gambar 1. Kerangka Konsep Penelitian

\section{Hipotesis penelitian}

H1 : Country of Origin berpengaruh postitif terhadap Brand Image. Country of Origin Perception (COO) adalah segala suatu bentuk persepsi konsumen atas produk dari suatu negara berdasarkan persepsi konsumen sebelumnya mengenai kelebihan dan kekurangan produksi dan pemasaran dari negara yang bersangkutan (Roth dan Romeo). Penelitian yang dilakukan oleh Permana (2013) telah membuktikan bahwa terjadi hubungan yang siginifikan antara Country of Origin dengan Brand Image serta hubungan yang signifikan antara Country of Origin dengan Purchase Intention.

H2 : Country of Origin berpengaruh postitif terhadap Purchase Intention. Penelitian yang dilakukan oleh Sankar (2006) yang berjudul "Consumer Perception of Global vs Local Brands: The Indian Car Industry “ menyatakan hasil bahwa adanya hubungan 
signifikan antara salah satu variabelnya yaitu COO terhadap Consumer Behavior terutama pada intensi pembelian oleh konsumen.

H3 : Perceived Quality berpengaruh postitif terhadap Brand Image. Menurut Krajewki dan Ritzman, persepsi kualitas (perceived quality) didefinisikan sebagai persepsi pelanggan terhadap keseluruhan kualitas atau keunggulan yang dimiliki oleh suatu produk atau jasa yang diharapkan. Persepsi ini bersifat relatif karena sesuai dengan padangan dan pikiran masing - masing konsumen. Kualitas dari suatu produk saat ini merupakan salah satu hal terpenting bagi konsumen sebagai bahan pertimbangan atas suatu merek produk.

H4 : Perceived Quality berpengaruh positif terhadap Purchase Intention. Penelitian yang dilakukan oleh Suprapti (2010) yang berjudul “Analisis Pengaruh Brand Awareness, Perceived Value, Oragnizational Association dan Perceived Quality Terhadap Keputusan Pembelian Konsumen" menyatakan hasil bahwa memang terjadi hubungan yang signifikan antara Perceived Quality dengan Keputusan Pembelian yang dilakukan oleh konsumen, dimana konsumen dengan melihat produk dan memiliki persepsi yang baik atas kualitas produk tersebut konsumen dapat langsung memutuskan untuk membeli produk tersebut.

H5 : Promotional Mix berpengaruh postitif terhadap Brand Image. Promotional mix akan mempengaruhi consumer perception yaitu bagaimana manusia memahami dan memproses ransangan sensorik melalui panca indra. Menurut Kotler (2009), persepsi merupakan proses di mana individu memilih, mengatur, dan menerjemahkan masukan informasi yang ada untuk menciptakan gambaran dunia yang berarti.

H6 : Promotional Mix berpengaruh postitif terhadap Purchase Intention. Penelitian yang dilakukan oleh Kazmi (2012) yang berjudul "Consumer Perception and Buying Decisions (The Pasta Study)" menyatakan bahwa consumer perception memiliki hubugan yang signifikan terhadap keinginan dan keputusan konsumen untuk membeli suatu produk. Pernyataan tersebut dibuktikan oleh Kazmi pada studi nya yaitu The Pasta Study dimana ia melakukan sampling kepada beberapa ibu rumah tangga mengenai pasta yang dijual di pasaran. Adapun persepsi yang dimiliki oleh konsumen meliputi dari pasta itu sendiri hingga cara memasaknya.

H7 : Brand Image berpengaruh positif terhadap Purchase Intention. Adanya informasi yang ada saat ini sering sekali digunakan oleh konsumen untuk mengevaluasi citra dari merek tersebut yang nantinya akan bisa merubah perilaku konsumen untuk melakukan pembelian atau tidak. Pada penelitian yang dilakukan oleh Permana (2013) 
yang berjudul "Pengaruh Country of Origin, Brand Image dan Persepsi Kualitas Terhadap Intensi Pembelian pada Merek" menyatakan bahwa brand image memiliki hubungan yang signifikan terhadap intensi pembelian atas suatu merek. Kerangka konsep dalam penelitian ini, ditunjukan pada Gambar 1.

\section{METODOLOGI PENELITIAN}

Penelitian ini termasuk penelitian asosiatif yaitu bertujuan menjelaskan hubungan atau pengaruh variabel Country of Origin Perception, Perceived Quality dan Promotion terhadap Brand Image dan Purchase Intention. Penelitian ini akan dilakukan di kota Denpasar mengingat kota Denpasar sebagai pusat pemerintahan dan bisnis.

Populasi penelitian ini adalah seluruh masyarakat pengguna smartphone yang ingin mengganti atau masyarakat yang berkeinginan membeli smartphone yang ada di kota Denpasar. Jumlah sampel yang digunakan dalam penelitian ini yaitu 125 orang responden karena sudah memenuhi syarat untuk dapat menggunakan Maximum Likelihood (M) sebagai model estimasi. Teknik sampling yang dimaksud adalah Purposive Sampling, yaitu teknik pengambilan sampel dengan kriteria tertentu.

Metode pengumpulan data dalam penelitian ini adalah dengan teknik wawancara penyebaran kuisioner yang secara langsung disebarkan oleh peneliti dan diukur menggunakan Skala Likert. Penelitian ini menggunakan alat pengumpul data berupa kuisioner, sehingga dengan begitu perlu dilakukan pengujian validitas dan reliabilitas sehingga dengan begitu kuisioner tersebut layak untuk digunakan.

Teknik analisis data penelitian ini menggunakan metode analisis alat analisis data yang digunakan yaitu Structural Equation Modeling atau SEM, yang dioperasikan melalui program AMOS 16.

\section{HASIL DAN PEMBAHASAN}

Karakteristik responden dikelompokan berdasarkan demografinya yang terdiri dari jenis kelamin, usia, pendidikan terakhir yang diselesaikan, jumlah pendapatan, dan pekerjaan. Pengelompokan berdasarkan jenis kelamin didominasi oleh laki-laki dengan jumlah responden sebanyak 75 orang dengan presentase sebesar 56 persen, sedangkan jumlah responden perempuan sebanyak 50 orang dengan presentase sebesar 44 persen. 
Pengelompokan berikutnya berdasarkan rentang usia, mayoritas usia 17-21 tahun mendominasi sebesar 63 persen, usia 22-26 sebesar 27,2 persen, usia $\geq 37$ sebanyak 11.2 persen, usia 32-36 sebanyak 8.8 persen, sedangkan usia 27-31 hanya sebanyak 2.4 persen.

Berdasarkan jenjang pendidikan yang telah diselesaikan, menunjukkan bahwa mayoritas responden dengan pendidikan terakhir yang diselesaikan SLTA sebesar 60 persen, diikuti dengan S1 sebesar 13.6 persen, pendidikan SMP sebesar 9.6 persen, diploma dan Pascasarjana masing-masing 7.2 persen dan posisi terakhir jenjang pendidikan SD sebesar 2.4 persen.

Tabel 1. Hasil Pengujian Validitas dan Reliabilitas

\begin{tabular}{|c|c|c|c|c|c|c|}
\hline \multirow[b]{2}{*}{ No. } & \multirow[b]{2}{*}{ Variabel } & \multirow[b]{2}{*}{ Item } & \multicolumn{2}{|l|}{ Validitas } & \multicolumn{2}{|l|}{ Reliabilitas } \\
\hline & & & Korelasi r & Ket & $\begin{array}{l}\text { Alpha } \\
\text { Cronbach }\end{array}$ & Ket \\
\hline \multirow[t]{7}{*}{1} & Country of the Origin & $\mathrm{X} 1.1$ & 0.750 & Valid & \multirow{7}{*}{0.840} & \multirow{7}{*}{ Reliabel } \\
\hline & & $\mathrm{X} 1.2$ & 0.782 & Valid & & \\
\hline & & $\mathrm{X} 1.3$ & 0.793 & Valid & & \\
\hline & & $\mathrm{X} 1.4$ & 0.687 & Valid & & \\
\hline & & X1.5 & 0.825 & Valid & & \\
\hline & & X1.6 & 0.756 & Valid & & \\
\hline & & $\mathrm{X} 1.7$ & 0.368 & Valid & & \\
\hline \multirow[t]{7}{*}{2} & Perceived Quality & $\mathrm{X} 2.1$ & 0.858 & Valid & \multirow{7}{*}{0.925} & \multirow{7}{*}{ Reliabel } \\
\hline & & $\mathrm{X} 2.2$ & 0.895 & Valid & & \\
\hline & & $\mathrm{X} 2.3$ & 0.864 & Valid & & \\
\hline & & $\mathrm{X} 2.4$ & 0.875 & Valid & & \\
\hline & & $\mathrm{X} 2.5$ & 0.808 & Valid & & \\
\hline & & $\mathrm{X} 2.6$ & 0.767 & Valid & & \\
\hline & & $\mathrm{X} 2.7$ & 0.759 & Valid & & \\
\hline \multirow[t]{2}{*}{3} & Promotional mix & $\mathrm{X} 3.1$ & 0.881 & Valid & \multirow[t]{2}{*}{0.751} & \multirow[t]{2}{*}{ Reliabel } \\
\hline & & $\mathrm{X} 3.2$ & 0.911 & Valid & & \\
\hline \multirow[t]{7}{*}{4} & Brand Image & Y1.1 & 0.747 & Valid & \multirow{7}{*}{0.902} & \multirow{7}{*}{ Reliabel } \\
\hline & & Y1.2 & 0.863 & Valid & & \\
\hline & & Y1.3 & 0.852 & Valid & & \\
\hline & & Y1.4 & 0.889 & Valid & & \\
\hline & & Y1.5 & 0.512 & Valid & & \\
\hline & & Y1.6 & 0.864 & Valid & & \\
\hline & & Y1.7 & 0.789 & Valid & & \\
\hline \multirow[t]{2}{*}{5} & Purchase Intention & Y 2.1 & 0.927 & Valid & \multirow{2}{*}{0.838} & \multirow{2}{*}{ Reliabel } \\
\hline & & Y2.2 & 0.929 & Valid & & \\
\hline
\end{tabular}




\section{Hasil Pengujian Instrumen Penelitian}

Hasil pengujian instrumen penelitian dengan uji validitas dan reliabilitas menunjukan nilai yang valid dan reliabel. Tabel 1 menunjukan hasil pengujian uji validitas dan reliabilitas.

\section{Hasil Model Pengukuran (Measurement Model)}

Uji kesesuaian model (Goodness of Fit Test)

Tabel 2. Estimasi Regression Weights

\begin{tabular}{|c|c|c|c|c|c|c|c|}
\hline & & & $\begin{array}{r}\text { Estimate } \\
\text { Unst }\end{array}$ & S.E. & $\begin{array}{r}\text { Estimate } \\
\text { Stand }\end{array}$ & C.R. & $\mathrm{P}$ \\
\hline $\mathrm{x} 1.1$ & $<---$ & $\mathrm{COO}$ & 1.364 & 0.173 & 0.853 & 7.864 & $* * *$ \\
\hline $\mathrm{x} 1.2$ & $<---$ & $\mathrm{COO}$ & 1.075 & 0.145 & 0.78 & 7.427 & $* * *$ \\
\hline $\mathrm{x} 1.3$ & $<---$ & $\mathrm{COO}$ & 1.201 & 0.156 & 0.823 & 7.712 & $* * *$ \\
\hline $\mathrm{x} 1.4$ & $<---$ & $\mathrm{COO}$ & 1.224 & 0.16 & 0.811 & 7.639 & $* * *$ \\
\hline $\mathrm{x} 1.5$ & $<---$ & $\mathrm{COO}$ & 1.135 & 0.155 & 0.757 & 7.338 & $* * *$ \\
\hline $\mathrm{x} 1.6$ & $<---$ & $\mathrm{COO}$ & 0.953 & 0.137 & 0.709 & 6.935 & $* * *$ \\
\hline $\mathrm{x} 1.7$ & $<---$ & $\mathrm{COO}$ & 1 & & 0.647 & & \\
\hline $\mathrm{x} 2.1$ & $<---$ & Perc_quality & 0.976 & 0.075 & 0.867 & 13.066 & $* * *$ \\
\hline $\mathrm{x} 2.2$ & $<---$ & Perc_quality & 0.832 & 0.078 & 0.769 & 10.658 & $* * *$ \\
\hline $\mathrm{x} 2.3$ & $<---$ & Perc_quality & 0.955 & 0.071 & 0.869 & 13.414 & $* * *$ \\
\hline $\mathrm{x} 2.4$ & $<---$ & Perc_quality & 0.904 & 0.075 & 0.828 & 12.123 & $* * *$ \\
\hline $\mathrm{x} 2.5$ & $<---$ & Perc_quality & 0.858 & 0.083 & 0.751 & 10.33 & $* * *$ \\
\hline $\mathrm{x} 2.6$ & $<---$ & Perc_quality & 0.917 & 0.076 & 0.83 & 12.078 & $* * *$ \\
\hline$x 2.7$ & $<---$ & Perc_quality & 1 & & 0.871 & & \\
\hline $\mathrm{x} 3.1$ & $<---$ & Promotion $\quad \operatorname{mix}$ & 1.298 & 0.185 & 0.831 & 6.997 & $* * *$ \\
\hline $\mathrm{x} 3.2$ & $<---$ & Promotion mix & 1 & & 0.697 & & \\
\hline $\mathrm{y} 1.1$ & $<---$ & Brand image & 1.186 & 0.138 & 0.823 & 8.596 & $* * *$ \\
\hline $\mathrm{y} 1.2$ & $<---$ & Brand image & 1.194 & 0.135 & 0.849 & 8.839 & $* * *$ \\
\hline $\mathrm{y} 1.3$ & $<---$ & Brand image & 1.285 & 0.149 & 0.832 & 8.643 & $* * *$ \\
\hline $\mathrm{y} 1.4$ & $<---$ & Brand image & 1.013 & 0.132 & 0.729 & 7.688 & $* * *$ \\
\hline $\mathrm{y} 1.5$ & $<---$ & Brand image & 1.212 & 0.141 & 0.828 & 8.594 & $* * *$ \\
\hline y1.6 & $<---$ & Brand image & 1.121 & 0.139 & 0.756 & 8.056 & $* * *$ \\
\hline $\mathrm{y} 1.7$ & $<---$ & Brand image & 1 & & 0.698 & & \\
\hline $\mathrm{y} 2.1$ & $<---$ & Purchase_int & 1.035 & 0.086 & 0.903 & 12.013 & $* * *$ \\
\hline $\mathrm{y} 2.2$ & $<---$ & Purchase_int & 1 & & 0.866 & & \\
\hline
\end{tabular}

Tabel 2 menunjukkan bahwa semua indikator yang membentuk variabel laten memiliki muatan faktor di atas 0,5 dengan nilai signifikansi di bawah 0,05 sehingga dapat dikatakan bahwa indikator-indikator yang membentuk konstruk adalah valid. 
Tabel 3 menunjukan hasil goodness of fit nilainya yang dipersyarakan yaitu $\geq 0,90$ sudah sebagian besar memenuhi persyaratan sehingga model sudah dapat dikatakan fit.

Tabel 3. Goodness of Fit Indexes Model

\begin{tabular}{cccl}
\hline Goodness of Fit Index & Cut of Value & Hasil Model & Keterangan \\
\hline Probability $(P)$ & $\geq 0,05$ & 0,071 & Baik \\
$X^{2}$-Chi-Square & $<321,48$ & 299,505 & Baik \\
& $(\mathrm{df}=265, \alpha=0,05)$ & & \\
CMIN/DF & $\leq 2,00$ & 1,130 & Baik \\
GFI & $\geq 0,90$ & 0,847 & Marginal \\
TLI & $\geq 0,95$ & 0,982 & Baik \\
CFI & $\geq 0,95$ & 0,984 & Baik \\
RMSEA & $\leq 0,08$ & 0,032 & Baik \\
AGFI & $\geq 0,90$ & 0,813 & Marginal \\
\hline
\end{tabular}

Sumber: Ferdinand (2002)

\section{Uji Reliabilitas Konstruk}

Tabel 4. Hasil Uji Reliabilitas

\begin{tabular}{lcc}
\hline Konstruk & Variance Extract & Construct Reliability \\
\hline COO & 0,60 & 0,91 \\
Perceive quality & 0,69 & 0,94 \\
Promotion Mix & 0,59 & 0,74 \\
Brand Image & 0,62 & 0,92 \\
Purchase_int & 0,78 & 0,88 \\
\hline
\end{tabular}

Tabel 4 dapat diketahui bahwa semua indikator mampu menjelaskan konstruk yang ada. Hal itu dapat dilihat dari angka construct reliability yang bernilai di atas 0,7 sehingga indikator-indikator tersebut dapat dikatakan reliabel. Semua indikator mampu menjelaskan konstruk yang ada. Hal itu dapat dilihat dari angka variance extracted $\geq 0,5$.

\section{Hasil Analisis Uji SEM}

\section{Uji Normalitas Data}

Tabel 5 menunjukan hasil uji normalitas univariat dan multivariat data dalam penelitian ini, oleh karena salah satu kriteria sudah terpenuhi, dalam hal ini Critical Ratio Skewness nya tidak berada diluar $\pm 2,58$, maka dapat dinyatakan bahwa data untuk masingmasing variabel dalam penelitian ini mempunyai sebaran yang normal. 
Tabel 5. Nilai Normalitas Data

\begin{tabular}{lrrrrrr}
\hline Variable & min & max & skew & c.r. & kurtosis & c.r. \\
\hline y1.7 & 2.000 & 5.000 & -.172 & -.785 & -1.342 & -3.063 \\
y1.6 & 2.000 & 5.000 & -.085 & -.388 & -1.445 & -3.297 \\
x2.7 & 2.000 & 5.000 & .080 & .364 & -1.441 & -3.289 \\
x2.6 & 2.000 & 5.000 & -.012 & -.053 & -1.357 & -3.097 \\
x2.5 & 2.000 & 5.000 & -.095 & -.436 & -1.437 & -3.279 \\
x1.7 & 2.000 & 5.000 & -.090 & -.409 & -1.457 & -3.326 \\
x1.6 & 2.000 & 6.000 & .152 & .693 & -.980 & -2.236 \\
y1.5 & 2.000 & 5.000 & -.379 & -1.731 & -1.280 & -2.922 \\
x3.1 & 2.000 & 5.000 & -.017 & -.078 & -1.548 & -3.532 \\
y1.4 & 2.000 & 5.000 & -.084 & -.385 & -1.238 & -2.826 \\
y1.1 & 2.000 & 5.000 & -.211 & -.963 & -1.358 & -3.099 \\
y1.2 & 2.000 & 5.000 & -.302 & -1.379 & -1.242 & -2.835 \\
y1.3 & 1.000 & 5.000 & -.138 & -.628 & -1.395 & -3.183 \\
x3.2 & 2.000 & 5.000 & .170 & .774 & -1.306 & -2.981 \\
x2.4 & 1.000 & 5.000 & -.026 & -.118 & -1.187 & -2.710 \\
x2.3 & 2.000 & 5.000 & .053 & .243 & -1.342 & -3.063 \\
y2.2 & 2.000 & 5.000 & -.083 & -.380 & -1.537 & -3.508 \\
y2.1 & 1.000 & 5.000 & -.005 & -.022 & -1.421 & -3.244 \\
x2.2 & 2.000 & 5.000 & -.065 & -.297 & -1.295 & -2.956 \\
x1.5 & 2.000 & 5.000 & -.082 & -.374 & -1.423 & -3.248 \\
x2.1 & 1.000 & 5.000 & -.053 & -.243 & -1.281 & -2.924 \\
x1.1 & 1.000 & 5.000 & -.180 & -.821 & -1.403 & -3.201 \\
x1.2 & 2.000 & 5.000 & -.034 & -.155 & -1.347 & -3.074 \\
x1.3 & 2.000 & 5.000 & -.101 & -.463 & -1.309 & -2.988 \\
x1.4 & 2.000 & 5.000 & .030 & .136 & -1.383 & -3.157 \\
\hline Multivariate & & & & & 41.877 & 6.371 \\
\hline & & & & & &
\end{tabular}

\section{Hasil Uji Outliers}

Untuk mendeteksi multivariete outliers adalah dengan menggunakan Uji Mahalanobis distance yang menunjukkan seberapa jauh jarak sebuah data dari pusat titik tertentu (Santoso, 2007). Batas nilai Mahalanobis distance berdasarkan $X_{(25 ; 0,01)}^{2}=44,31$. Jika nilai Mahalanobis $d$-squared > 44,31 maka data tersebut dikatakan outliers. Berdasarkan hasil analisis pada Lampiran 5 (output Observations farthest from the centroid (Mahalanobis distance) (Group number 1), t ditemukan ada empat nilai Mahalanobis $d$-squared lebih besar dari 44,31. Jumlah tersebut sangat kecil jika dilihat dari sampel yang berjumlah 125 sehingga tidak ada alasan untuk membuangnya. Dengan demikian data dapat dikatakan terbebas dari outlier (Ferdinand, 2002) 


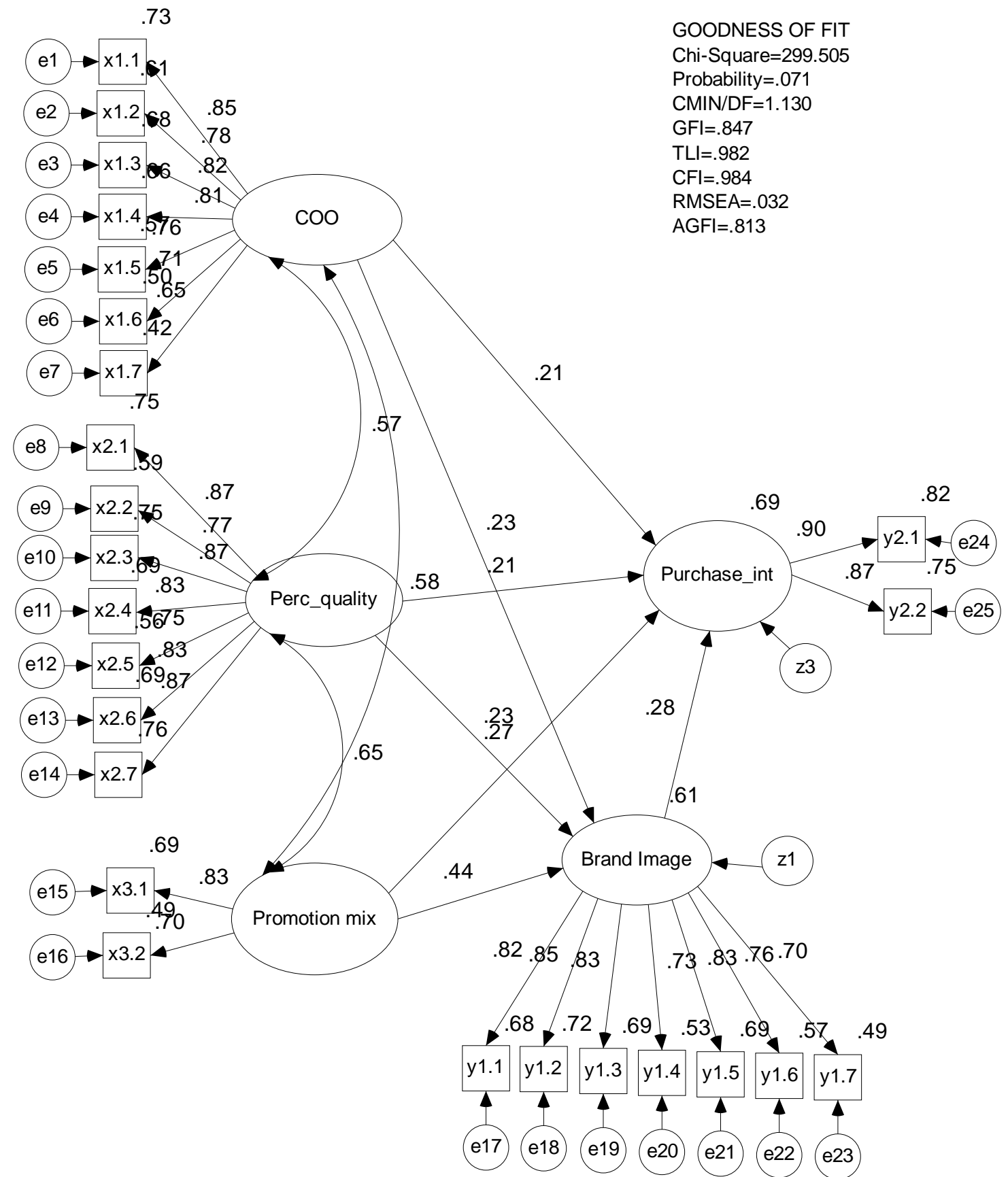

Gambar 2. Model Pengaruh COO, Perceived Quality dan Promotional Mix terhadap Purchase Intentetion dengan Brand Image Sebagai Intervening Variabel

\section{Hasil Uji Multikolinieritas dan Singularitas}

Multikolinieritas dapat dideteksi dari determinan matriks kovarians. Nilai determinan matriks kovarians yang sangat kecil memberi indikasi adanya problem multikolinieritas dan singularitas (Ferdinand, 2002). Nilai output determinant of sample covariance matrix (Lampiran 5) adalah 0,0000639. Nilai tersebut jauh dari nol, sehingga 
dapat dinyatakan tidak ada multikolinieritas dan singularitas. Dengan demikian data dalam penelitian ini layak untuk digunakan.

\section{Hasil Estimasi Regressions Weights}

Tabel 6. Estimasi Regression Weights Model Pengaruh COO, Perceived Quality dan Promotional Mix terhadap Brand Image dan Purchase Intentetion

\begin{tabular}{lllccccc}
\hline & & & $\begin{array}{c}\text { Estimate } \\
\text { Unstandardize }\end{array}$ & S.E. & $\begin{array}{c}\text { Estimate } \\
\text { Standardize }\end{array}$ & C.R. & $\begin{array}{c}\text { P } \\
\text { Value }\end{array}$ \\
\hline Brand Image & $<---$ & Promotion_mix & 0.435 & 0.138 & 0.437 & 3.149 & 0.002 \\
Brand Image & $<---$ & COO & 0.240 & 0.105 & 0.234 & 2.297 & 0.022 \\
Brand Image & $<---$ & Perc_quality & 0.173 & 0.083 & 0.227 & 2.071 & 0.038 \\
Purchase_int & $<---$ & Promotion_mix & 0.369 & 0.187 & 0.273 & 1.975 & 0.048 \\
Purchase_int & $<---$ & COO & 0.293 & 0.132 & 0.211 & 2.226 & 0.026 \\
Purchase_int & $<---$ & Perc_quality & 0.220 & 0.107 & 0.213 & 2.065 & 0.039 \\
Purchase_int & $<---$ & Brand Image & 0.378 & 0.164 & 0.279 & 2.306 & 0.021 \\
\hline
\end{tabular}

Sumber: Hasil Analisis SEM

Berdasarkan hasil estimasi standardized regressions weights pada Tabel 6 dapat diketahui bahwa koefisien jalur Country Of the Origin (COO) terhadap Brand Image adalah sebesar 0,240 dengan tingkat signifikansi sebesar 0,022. Hal ini menunjukkan bahwa ada pengaruh yang signifikan antara COO terhadap Brand Image. Konstruk Perceived quality berpengaruh signifikan terhadap Brand image dengan koefisien jalur sebesar 0,172 dengan nilai signifikansi sebesar 0,038. Demikian juga konstruk Promotional mix berpengaruh signifikan terhadap Brand image dengan koefisien jalur sebesar 0,435 dengan nilai signifikansi sebesar 0,002.

Koefisien jalur COO terhadap Purchase intention adalah sebesar 0,293 dengan tingkat signifikansi sebesar 0,026. Hal ini menunjukkan bahwa ada pengaruh yang signifikan antara COO terhadap Purchase intention. Konstruk Perceived quality berpengaruh signifikan terhadap Purchase intention dengan koefisien jalur sebesar 0,220 dengan nilai signifikansi sebesar 0,039. Konstruk Promotional mix berpengaruh signifikan terhadap Purchase intention dengan koefisien jalur sebesar 0,369 dengan nilai signifikansi sebesar 0,048. Demikian juga konstruk Brand Image berpengaruh signifikan terhadap Purchase intention dengan koefisien jalur sebesar 0,378 dengan nilai signifikansi sebesar 0,021 . 
Analisis Pengaruh Langsung, Tidak Langsung, dan Pengaruh Total

Tabel 7. Pengaruh Langsung, Pengaruh Tidak Langsung dan Pengaruh Total COO, Perceived Quality, Promotional Mix terhadap Brand Image dan Purchase intention

\begin{tabular}{llc} 
Tipe Pengaruh & \multicolumn{1}{c}{ Konstruk } & $\begin{array}{c}\text { Standardized } \\
\text { Estimates }\end{array}$ \\
\hline Pengaruh Langsung & COO - Brand Image & 0,240 \\
& Perceived quality-Brand Image & 0,173 \\
& Promotional Mix - Brand Image & 0,435 \\
& COO - Purchase intetion & 0,293 \\
& Perceived quality - Purchase intention & 0,220 \\
Pengaruh tak & Promotional mix - Purchase intention & 0,369 \\
Langsung & Brand image - Purchase intention & 0,378 \\
& COO - Purchase intetion & 0,065 \\
& Perceived quality - Purchase intention & 0,063 \\
& Promotional mix - Purchase intention & 0,122 \\
Pengaruh Total & COO - Purchase intetion & 0,276 \\
& Perceived quality - Purchase intention & 0,277 \\
& Promotional mix - Purchase intention & 0,395 \\
& Brand image - Purchase intention & 0,279 \\
\hline
\end{tabular}

Sumber : Hasil Analisis SEM

\section{KESIMPULAN DAN SARAN}

Dari hasil analisis dan pembahasan dapat disimpulkan sebagai berikut :

1. Terdapat pengaruh yang signifikan antara Country of Origin Perception, Perceived Quality dan Promotional Mix terhadap Brand Image produk smartphone buatan Indonesia

2. Terdapat pengaruh yang signifikan antara Country of Origin Perception, Perceived Quality dan Promotional Mix terhadap Purchase intention produk smartphone buatan Indonesia

3. Terdapat pengaruh yang signifikan antara Brand Image terhadap Purchase intention produk smartphone buatan Indonesia 


\section{Saran}

Dengan memperhatikan hasil penelitian tersebut maka disarankan untuk pengembangan industri dalam negeri khususnya industri smartphone agar lebih meningkatkan kualitas smartphone dengan menambahkan fitur-fitur yang lebih canggih serta desain yang lebih menarik sesauai dengan kebutuhan konsumen. Dengan demikian smartphone buatan Indonesia mampu membangun keunggulan kompetitif sekaligus akan mampu nmengangkat reputasi Indonesia pada industri smartphone, hal ini sangat memungkinkan karena Indonesia memiliki potensi yang cukup tinggi terutama dari aspek sumber daya manusianya.

\section{DAFTAR PUSTAKA}

Bhakar, S, et.al. 2013. Relationship Between Country Of Origin, Brand Image and Customer Purchase Intentions."Far East Journal of Psychology and Business, Vol. 10, No. 2, h. $26-47$

Frontier. 2016. Brand Diagnostics dan Hasil Pengukuran Top Brand Index. www.frontier.co.id. diakses 8 Desember 2016

Ghalandari, Kamal and Abdollah Norouzi. 2012. The Effect of Country Of Origin on Purchase Intention: The Role of Product Knowledge. "Research Journal of Applied Sciences, Engineering and Technology, Vol. 4, No. 9, h. 1166 - 1171

Ghozali, Imam. 2013. Model Persamaan Struktural Konsep Aplikasi dengan Program AMOS 21.0. Edisi V. Semarang: Badan Penerbit Universitas Diponegoro

Kartajaya, Hermawan. 2010. Perjalanan Pemikiran Konsep Pemasaran Hermawan Kartajaya Dari Indonesia Untuk Dunia: Redefinisi, Simplifikasi, dan Futurisasi. Jakarta: PT Gelora Aksara Pratama

Kotler, Philip dan Kevin Lane Keller, 2009. Manajemen Pemasaran. Jakarta: PT. Erlangga

Made in . The Value od of Country of Origin for future brands. http://www.futurebrand.com/images/uploads/studies/cbi/MADE_IN_Final_HR.pdf diakses 19 September 2014

Permana \& Magyar Slamet, 2013. Pengaruh Country of Origin, Brand Image dan Persepsi Kualitas terhadap Intensi Pembelian Pada Merek.Fakultas Ekonomika dan Bisnis Universitas Satya Wacana, Salatiga.

Peter, J. Paul, Jerry C. Olson. 1999. Consumer Behaviour and Marketing Strategy. Edisi IV. Jakarta: PT Erlangga

Sekaran, Uma. 2007. Research Methods For Business. Edisi 4. Jakarta: Penerbit Salemba Empat

Shimp, Terence. A. 2003. Periklanan Promosi Aspek Tambahan Komunikasi Pemasaran Terpadu, Edisi Lima. Jakarta: PT Erlangga

Suprapti, Lilik. 2010. Ananalisis Pengaruh Brand Awarenes, Perceived Value, Organizational Association dan Perceived Quality terhadap Keputusan Pembelian Konsumen. Fakultas Ekonomika dan Bisnis Universitas Diponegoro, Semarang

Wibowo, Prabu Teguh. Pengaruh Brand Awareness, Brand Trust, dan Brand Image terhadap Keputusan Pembelian Obat Nyamuk Hit Liquid Spray di Kota Depok. Fakultas Ekonomi Universitas Gunadarma. Jakarta 
Wijaya, Dimas Surya. 2011. Analisis Pengaruh Ekuitas Merek Terhadap Keputusan Pembelian Handphone Blackberry (Studi Kasus pada Mahasiswa Fakultas Ekonomi Universitas Diponegoro Semarang). Fakultas Ekonomi Universitas Semarang 